I. Sakharuk, PhD (Law), Associate Professor

Taras Shevchenko National University of Kyiv, Kyiv, Ukraine

\title{
LEGAL WAYS FOR OVERCOMING GENDER DISPROPORTIONS IN THE UKRAINIAN LABOR MARKET
}

The article deals with the problems of improvement and implementation legislation for gender equality in Ukraine. Have been analysed the main manifestations of discrimination against women in labor market: vertical and horizontal occupational segregation; gender wage differentials; difficulties associated with the combination of work and family responsibilities; the overwhelming predominance of women in the field of part-time, informal, temporary employment; sexual harassment. The issues of gender segregation, gender pay gap, gender equality for work-life balance in the context of foreign and national experience have been explore.

The author have been determine the tendencies of improving the labor legislation in foreign countries for introducing the principle of equality between men and women. Gender mainstreaming strategies and programs in 620 countries were summarized. The author draw attention to the nonefficiency of State Social Program for Equal Rights and Opportunities for Women and Men for the period up to 2021, was made the proposals for its improvement

The study finds that there is the issue of equality opportunities between men and women in representation authorities at different levels in Ukraine (on the example of the Verkhovna Rada of Ukraine and the Cabinet of Ministers of Ukraine). Approaches to gender quotas in foreign countries have been analyzed. The author used the statistics on employment, entrepreneurship and remuneration to show inequality on the labor martet in Ukraine.

The author have also identified that the national legislation, which establishes special guarantees and restrictions on women's work, will have to be improve in the context of a substantive model of equality. Have been suggested the ways of overcoming gender discrimination in the workplace by a policy of affirmative action.

Keywords: gender equality, discrimination, gender segregation, labor market, electoral quotas, security legislation, affirmative action, differentiation of legal regulation.

References:

1. Equality at work: The continuing challenge: Global Report under the follow-up to the ILO Declaration on Fundamental Principles and Rights at Work. 27 April 2011. URL: https://www.ilo.org/ilc/ILCSessions/previous-sessions/100thSession/reports/reports-submitted/WCMS_154779/lang--en/index.htm.

2. Guide to developing balanced working time arrangements. International Labour Office. Geneva, ILO, 2019. 48 p. URL: https://www.ilo.org/ wcmsp5/groups/public/---ed_protect/---protrav/---travail/documents/publication/wcms_706159.pdf.

3. Women at Work in G20 countries: Progress and policy action since 2018. Report. 22 April 2019. 21 p. URL: https://www.ilo.org/global/about-theilo/how-the-ilo-works/multilateral-system/g20/reports/WCMS_713373/lang--en/index.htm.

4. Derzhavna social'na programa zabezpechennja rivnyh prav ta mozhlyvostej zhinok i cholovikiv na period do 2021 roku : Postanova Kabinetu Ministriv Ukrai'ny vid 11.04.2018 №273. Oficijnyj visnyk Ukrai'ny. 2018. №33. St.1165. (in Ukrainian).

5. The Global Gender Gap Report 2018. World Economic Forum. http://www3.weforum.org/docs/WEF_GGGR_2018.pdf.

6. Genderni aspekty rynku praci v Ukrai'ni: dopovid' [Gender aspects of the Ukrainian labor market: a report] / Derzhavna sluzhba statystyky Ukrai'ny. URL: http://www.ukrstat.gov.ua (in Ukrainian)

7. Try "ekzameny" dlja chynovnykiv: interv'ju Golovy Nacional'nogo agentstva z pytan' derzhavnoi' sluzhby. [Three Exams for Officials : Interview with the Head of the National Agency for Civil Service]. Den. 2019. № 72-73. URL: https://day.kyiv.ua/uk/article/cuspilstvo/try-ekzameny-dlya-chynovnykiv (in Ukrainian).

8. Demografichna ta social'na statystyka [Demographic and social statistics] / Derzhavna sluzhba statystyky Ukrai'ny. URL: http://www.ukrstat.gov.ua/ (in Ukrainian).

9. Zhinky ta choloviky na kerivnyh posadah v Ukrai'ni: statystychnyj analiz vidkrytyh danyh JeDRPOU [Women and men in senior management positions in Ukraine: statistical analysis of open EDRPOU data]. Veresen' 2017. URL: http://www.un.org.ua/images/documents/4531/Women_and_Men_inLeadership_Position.pdf (in Ukrainian).

10. Global Wage Report 2018/19: What lies behind gender pay gaps. International Labour Office. Geneva: ILO, 2018. 172 p. URL: https://www.ilo.org/ wcmsp5/groups/public/---dgreports/---dcomm/---publ/documents/publication/wcms 650553.pdf

11. Jefanova I., Marcenjuk T. Genderna nerivnist' na rynku praci Ukrai'ny u sferi informacijnyh tehnologij [Gender Inequality in the Labor Market of Ukraine in Information Technologies]. Visnyk Kyi'vs'kogo nacional'nogo universytetu imeni Tarasa Shevchenka. Sociologija. 2017. № 1(8). S. 10-16. (in Ukrainian).

12. Pro Rekomendacii' parlaments'kyh sluhan' na temu: "Rivni prava ta rivni mozhlyvosti v Ukrai'ni: realii' ta perspektyvy" : Postanova Verhovnoi' Rady Ukrai'ny vid 27 chervnja 2007 roku № 1241-V. Vidomosti Verhovnoi' Rady Ukrai'ny. 2007. № 45. St. 522 (in Ukrainian).

13. Prava ljudyny v Ukrai'ni - 2017. Dopovid' pravozahysnyh organizacij [Human rights in Ukraine - 2017 : Report of human rights organizations] / za red. O.M. Pavlichenka, O.A. Martynenka / Ukrai'ns'ka Gel'sins'ka spilka z prav ljudyny. K., 2018. URL: https://helsinki.org.ua/publications/richna-dopovidpravozahysnyh-orhanizatsij-prava-lyudyny-v-ukrajini-2017/ (in Ukrainian).

14. Saharuk I.S. Pravove reguljuvannja rivnyh prav i mozhlyvostej okremyh kategorij pracivnykiv [Legal regulation of equal rights and opportunities of certain categories of employees]. Naukovyj visnyk Chernivec'kogo universytetu. Pravoznavstvo. 2010. Vyp. 533. S. 49-55.

15. Dashkovs'ka O. R. Problemy vprovadzhennja pryncypu gendernoi' rivnosti $\vee$ ukrai'ns'ke zakonodavstvo: zagal'noteoretychni aspekty [Problems of implementation of the principle of gender equality in Ukrainian legislation: general theoretical aspects.]. Problemy zakonnosti. 2002. № 52. S. 9-15 (in Ukrainian).

16. Final'nyj zvit za rezul'tatamy g'endernogo monitoryngu na miscevyh vyborah 2015 roku v Ukrai'ni [Final report on the results of gender monitoring at the 2015 local elections in Ukraine] / VGO "Komitet vyborciv Ukrai'ny". URL http://www.cvu.org.ua/nodes/view/type:news/slug:finalnyi-zvit-za-rezultatamygendernogo-monitoryngu-2015 (in Ukrainian).

УДК 343.131; $343.132(477)$

О. Юхно, д-р юрид. наук, проф. Харківський національний університет внутрішніх справ, Харків, Україна

\section{ПРОБЛЕМНІ ПИТАННЯ ЗАКОНОДАВЧОГО І ПРИКЛАДНОГО УДОСКОНАЛЕННЯ ПОЧАТКОВОГО ЕТАПУ ДОСУДОВОГО РОЗСЛІДУВАННЯ}

Здійснено порівняльний аналіз попереднього і чинного кримінального процесуального законодавства України стосовно процесуального інституту початку досудового розслідування. Встановлені певні прогалини і неузгодженості в чинному КПК України, що викликає нарікання від учасників кримінального проваження у правозастосовній діяльності, а також дискусію серед учених і практиків із цих питань. Надано пропозиції з удосконалення чинного законодавства стосовно порушених проблем.

Ключові слова : початок розслідування, кримінальне провадження, удосконалення, повідомлення, слідчий, прокурор, розкриття, регламентація.

Вступ. Завдяки дослідженням встановлено, що початок досудового розслідування та процесуальні права учасників кримінального провадження на цьому етапі досудового розслідування недостатньо за- конодавчо врегульовано у чинному КПК України, на відміну від КПК України 1960 р. Це слід пояснити сталими та дискусійними підходами в науці, що така діяльність $€$ як процесуальною, так і непроцесуаль- 
ною. Згідно з положеннями ст. 214 чинного КПК України досудове розслідування розпочинається з моменту внесення відповідних відомостей до Єдиного реєстру досудових розслідувань (ЄРДР). Слідчим, прокурором це здійснюється невідкладно, але не пізніше 24 год після подання (отримання) заяви або повідомлення про вчинений злочин. Утім, процесуальний механізм зазначеного етапу досудового розслідування після набуття чинності КПК України 2012 р. викликав дискусію щодо цих питань з боку вчених, практиків і зауваження учасників кримінального провадження, як з боку обвинувачення, так і з боку захисту. На відміну від КПК України 1960 р., у чинному КПК України відсутня регламентація щодо складання процесуального документа, яким хоча б орієнтовно визначався і підтверджувався початок досудового розслідування. Відсутність такого процесуального документа нині сприймається як суттєвий недолік і викликає доречні нарікання з аргументацією про те, що саме це призводить до порушень і незабезпечення прав, свобод і законних інтересів учасників кримінального провадження. Така прогалина призводить, з одного боку, до несвоєчасного інформування учасників кримінального провадження про його початок і першопочаткові дії на досудовому розслідуванні, а 3 іншого - не дає можливості учасникам кримінального провадження реалізувати своє право на своєчасне надання певних доказів, додаткової та уточнюючої інформаціїі порівняно з тією, що була, наприклад, подана в заяві чи повідомленні про злочин до слідчих підрозділів, а також своє право на оскарження. Залишаються дискусійними теоретичні і прикладні питання про приводи та підстави, що могли б служити початку досудового розслідування. Зазначені питання продовжують бути законодавчо неврегульованими, незважаючи на наявні новели, що закріплені в положеннях КПК України.

Аналіз останніх досліджень і публікацій. Новели чинного КПК України викликали неоднозначні наукові позиції науковців та практиків. Удосконалення кримінального процесуального законодавства України та його інститутів, зокрема щодо початку досудового розслідування, були та залишаються предметом активної наукової дискусії. Ці питання розглядались у працях: Ю. Азарова, Ю. Аленіна, А. Бабича, І. Басистої, О. Балашов, В. Боярова, О. Вакулика, В. Вапнярчука, Т. Варфоломеєвої, В. Галагана, Ю. Грошевого, А. Дубинського, В. Зеленецького, О. Капліної, Л. Лобойка, Є. Лук'янчикова, В. Маляренка, Ю. Манаєва, О. Михайленка, М. Михеєнка, В. Нора, Д. Письменного, М. Погорецького, В. Попелюшка, С. Стахівського, О. Татарова, В. Тертишника, Л. Удалової, С. Чернявського, В. Шибіки, М. Шумили, О. Яновської та ін. Згадані й інші вчені внесли значний внесок у розроблення такої проблематики, однак їхні дослідження стосувалися переважно попереднього законодавства 1960 р. та проблем правозастосовної практики його запровадження. Ретельне дослідження недоліків і прогалин, що містяться у положеннях ст. 214 чинного КПК України, а також проблем її правозастосування у 2013 р. провів Ю. Аленін [15, с. 198-203]. Сучасне дослідження і розроблення проблематики, що присвячено вивченню питань процесуальної діяльності слідчого та прокурора на початку досудового розслідування після прийняття чинного КПК України проведено ученими О. Вакуліком і Ю. Азаровим у 2015 р. [9, с. 184 ], а питання щодо приводів і підстав для початку досудового розслідування у 2015 р. й подальші роки досліджував А. Погорецький [7, с. 93-103]. У дискусії та у відповідних дослідженнях узяли участь й інші вчені. Однак нині у КПК України після 2012 р. внесено понад 570 змін і доповнень, а правозастосовна практика висуває додаткові проблемні питання щодо їхнього розв'язання, у зв'язку з чим дослідження із зазначених питань доцільно продовжувати. Це підкреслює актуальність такого наукового дослідження і нагальну потребу законодавчого удосконалення та нормативно-правової регламентації внесення відомостей до Єдиного реєстру досудових розслідувань (ЄРДР), а також уточнення процесуального порядку та механізму початку досудового розслідування на цьому історичному етапі.

Формування цілей. На основі порівняльного аналізу визначити окремі аспекти позитивного підходу i наявної недосконалості попереднього та чинного КПК України щодо процесуальних питань та механізму початку досудового розслідування і напрацювати пропозиції та рекомендації щодо удосконалення положень чинного КПК України і практики правозастосовної діяльності з вказаних питань.

Методологія дослідження. Для досягнення поставленої мети та завдань використано загальнонаукові методи дослідження. За допомогою історичного методу здійснено дослідження початку кримінального провадження за вимогами попереднього КПК України 1960 р. Метод юридичного аналізу використовувався для усвідомлення змісту норм кримінального процесуального законодавства та відомчих нормативно-правових актів, що регламентують порядок здійснення початку досудового розслідування. Для порівняння норм національних законодавчих актів, що регулюють досліджений процесуальний інститут та окремих зарубіжних країн, зокрема країн пострадянського простору, використано порівняльно-правовий метод.

Результати. У зв'язку з приєднанням до Ради Європи 9 листопада 1995 р., правова реформа, що проводиться в Україні, має забезпечити якісні й ефективні зміни у діяльності правоохоронних органів і суду щодо протидії злочинності. У цих умовах особливого значення набувають питання удосконалення й ефективності процесуального інституту початку досудового розслідування, оскільки недосконалість його правової регламентації завдає шкоди інтересам держави і правосуддя, порушуючи при цьому процесуальні права сторін та викликає негативну реакцію учасників кримінального провадження. Це обмежує права потерпілого й інших учасників кримінального провадження та може приводити до порушення однієї із засад кримінального провадження - презумпції невинуватості. При опрацюванні проекту нового КПК України, процесуалісти висловлювали різні думки щодо запровадження нової процедури початку кримінального провадження. За визначенням Л. Лобойка, ще під час підготовки проекту КПК України Національною комісією зі зміцнення демократії та утвердження верховенства права, не було більш дискусійного питання, ніж питання про необхідність подальшого існування стадії порушення кримінальної справи [1, с. 251-252]. У чинному КПК України скасовано процедуру проведення тривалої перевірки заяв і повідомлень про вчинені злочини та необхідність ухвалення відповідного процесуального рішення, зокрема про відмову в порушенні кримінальної справи. Процесуальний інститут початку криміна- 
льного провадження зазнав суттєвих змін, яким було істотно змінено його процесуальне регулювання із порушення кримінальної справи на інший початок кримінального провадження. Нині він розпочинається згідно з п. 5 ч. 1 ст. КПК України з моменту реєстрації заяв і повідомлень про кримінальне правопорушення в ЄРДР, без оформлення слідчим, прокурором будьякого процесуального чи непроцесуального документу (напр., постанови про порушення кримінального провадження тощо). Водночас ця новела чинного КПК України не сприймається вченими і практиками беззаперечно. 3 огляду на це у правозастосовній діяльності виникають проблемні питання, що не сприяють належному виконанню завдань кримінального провадження відповідно до ст. 2 КПК України. Доцільно проаналізувати співвідношення положень попереднього КПК України 1960 р. і нині чинного, наукові позиції вчених у ході дискусії з проблемних питань, міжнародне законодавство щодо початку досудового розслідування. Наприклад, М. Кузнецов вважав, що кримінальний процес за КПК України 1960 р. починається не $з$ моменту порушення кримінальної справи (провадження на сьогодні), а з моменту надходження заяви або повідомлення, а також інших даних про вчинення чи підготовку злочину до органів, що були уповноважені ухвалювати щодо них рішення, тобто виникнення одного із закріплених у законі приводів до початку кримінального провадження. Саме із цього часу починалося реагування на злочин у формі кримінальної процесуальної діяльності, коли держава реагувала правовими заходами на дії або бездіяльність певної особи, що мають ознаки злочину [2, с. 7-8]. Водночас О. Балашов зазначав, що назва "порушення кримінальної справи" ототожнювалась із назвою процесуального документа, але не відображала фактичного змісту усієї відповідної діяльності, яка здійснювалася уповноваженими суб'єктами на цій стадії судочинства [3, с. 53-54]. Фактично рішення про порушення кримінальної справи за попереднім КПК України приймалось у формі постанови про порушення кримінальної справи. Однак такі вчені, як В. Тертишник, В. Маляренко, В. Зажицький та інші заперечували про застосування визначення поняття "порушення кримінальної справи", а пропонували цю стадію називати "перевіркою і розглядом заяв та повідомлень про злочин", оскільки на цій стадії кримінальні справи порушувались не завжди. Вони аргументували це тим, що поряд із порушенням кримінальної справи на той час існувала практика відмови в порушенні кримінальної справи (така постанова у 95 \% випадках від усіх зареєстрованих справ затверджувалась начальником райвідділу, у разі винесення ії̈ не слідчим). Так, згідно зі статистикою, у 2010 р. було незаконно відмовлено в порушенні кримінальних справ стосовно 24906 злочинів, у 2011 р. - 25 696, а до початку дії нового КПК України (20.11. 2012) - 9081 злочину.

У відмовних матеріалах у своїй більшості робилося посилання на: ст. 6 ч.1 (відсутність події злочину), ст. 6 ч. 2 (відсутність у діянні складу злочину) та на інші статті КПК України, а також і на ч. 1 ст. 7 КК України, згідно 3 якою на той час не вважалася дія або бездіяльність, що хоча формально й мала ознаки будь-якого злочину, передбаченого кримінальним законом, але з огляду на малозначність вони не представляли суспільної небезпеки. Малозначністю згідно з коментарем до КК України вважалося здійснення дії (бездіяльності) яке або взагалі не спричинило і не могло спричинити шкоду, або спричинило чи могло спричинити лише дуже незначну шкоду. Якщо в діяннях було встановлено ознаки, що зазначені в ч. 2 ст. 7 того КК України, то справа підлягала закриттю чи відмові в порушенні кримінальної справи) у зв'язку з відсутністю складу злочину згідно 3 п. 2 ст. 6 КПК України [4]. Після ухвалення КК України у 2001 р. посилання у відмовних матеріалах здійснювалось, крім згаданих уже ст. 6 п.1 та 6 п. 2 КПК України також і на ст. 48 КК України (оскільки норму ст. 7 КК щодо малозначності було замінено на ст. 11, але в новій редакції вона вже не застосовувалась), згідно з чим особа звільнялася від кримінальної відповідальності, якщо вчинила злочин невеликої або середньої тяжкості, або внаслідок зміни обстановки вчинене нею діяння втратило суспільну небезпечність або особа перестала бути суспільно небезпечною [5]. При цьому згідно 3 положеннями КПК України 1960 р. здійснювалась така практика: незалежно, чи виносилась постанова про порушення або відмову в порушенні кримінальної справи, усім зацікавленим особам у цих справах (матеріалах) і прокурору направлялось письмове повідомлення щодо прийнятого одного із зазначених рішень і вони мали можливість реалізувати своє право на захист та оскарження рішень. Водночас при розв'язанні зазначених питань допускались чисельні порушення законності. Наприклад, згідно з дослідженнями було всього притягнуто до дисциплінарної відповідальності за незаконну відмову в порушенні кримінальної справи за КПК України 1960 р. : у 2004 р. - 2257 осіб, з них керівників різного рівня - 249; у 2005 р. 2358, $з$ них керівників - 191; у 2006 р. - 2358, з них керівників - 269; у 2007 р. - 2687, з них керівників 263; у 2008 р. - 4261, з них керівників - 492; у 2009 р. - 4991, з них керівників - 527; у 2010 р. - 5497, з них керівників - 636; у 2011 р. - 5152, з них керівників 742; до 20.11. 2012 р. - 3937 осіб, з них керівників 804 [6, с. 590-591]. Це свідчить про такий негатив, як вплив керівників на регулювання необхідних показників та маніпуляції стосовно їх, зокрема з укриття, або підвищення відсотка розкриття злочинів.

Нині після реєстрації заяви або повідомлення в ЄРДР положення чинного КПК України не зобов'язують посадових осіб здійснювати відповідні письмові повідомлення учасникам кримінального провадження, що не дає можливості своєчасно захищати свої права або оскаржувати дії посадових осіб. Слід підтримати наукову позицію А. Аленіна, що механізм розпочинання досудового розслідування не передбачає здійснення за ним судового контролю, що не узгоджується 3 рішенням Конституційного Суду України у справі про розгляд судом окремих постанов слідчого і прокурора від 30 січня 2003 р. [15, с. 198-203]. Оцінюючи новели чинного КПК України М. Погорецький зауважив, що вони суттєво змінили початковий етап досудового розслідування, маючи на меті унеможливити конфрлікт між державою та громадянами з приводу їхніх звернень до правоохоронних органів із заявою чи повідомленням про вчинене кримінальне правопорушення, запобігаючи неприйняттю таких заяв чи повідомлень, відмові у їхньому вирішенні, а також створенню широких можливостей оперативного розгляду таких заяв i повідомлень, застосовуючи при цьому весь арсенал кримінальних процесуальних засобів. Крім цього він наголосив, що проблемним $€$ встановленння підстав i приводів при реєстрації заяв та повідомлень про злочин до ЄРДР [7, с. 93-94]. Підтримуючи зазначену позицію в частині скасування у чинному КПК України 
оформлення відмовних матеріалів, ми вважаємо, що такий процесуальний порядок дозволяє також уникати повторного проведення таких процесуальних дій, як: опитування, допиту, досліджень фахівців, експертних досліджень тощо. У ході дискусії з порушених питань Л. Черечукіна обґрунтувала, що рішенню уповноважених осіб "про порушення" або "початок" кримінального провадження має бути надана процесуальна форма у вигляді постанови і лише після цього відомості про злочин можуть бути внесені до ЄРДР [8 с. 5-12], що ми також підтримуємо. Зі свого боку О. Вакулик і Ю. Азаров зауважили, що слід вести мову про необхідність корегування законодавства, ніж ставити під сумнів процесуальний характер одного з визначальних рішень кримінального проваження [9, с. 63-64]. Аналізуючи КПК України і висловлені на сьогодні пропозиції окремих учених і практиків, слід підтримати їх у частині доцільності передбачення початку кримінального провадження у більш визначеній та певній процесуальній формі, тобто у винесенні відповідної постанови про його початок. Така пропозиція обґрунтовується трактуванням змісту положень ч. 3 ст. 110 чинного КПК України, у якій закріплено, що процесуальними рішеннями $є$ всі ті, які приймаються слідчим, прокурором у формі постанови, що виноситься у випадках регламентованих КПК України, а також тоді, коли це визнається необхідним зазначеними посадовими особами [19]. Це стосується і тих постанов які виносяться щодо проведення певної слідчої (розшукової) дії, що загалом направлено на виконання завдань кримінального провадження згідно зі ст. 2 КПК України.

Беручи участь у дискусії із цих питань і досліджуючи міжнародні процесуальні норми більшості країн пострадянського простору, у яких основним джерелом права $€$ кодекс, що забезпечує одноманітність застосування процесуальних норм, на відміну від західноєвропейських країн, де поряд із кодикіфрікованим законодавством велике значення має судовий прецедент, та вивчаючи регламентацію початку досудового розслідування, Г. Глобенко й інші вчені зауважують, що ст. 210 КПК Азербайджанської Республіки, ст. 175 Республіки Білорусь, ст. 175 КПК Вірменії, ст. 321 Республіки Узбекистан, ст. 156 Республіки Киргизстан, ст. 146 КПК Російської Федерації, закріпили стадію порушення кримінальної справи. Крім того, у КПК вищезгаданих країн регламентовано дослідчу перевірку за заявами та повідомленнями. Водночас досудове розслідування згідно з КПК у Грузії, Казахстані й Україні розпочинається з моменту внесення відомостей до ЄРДР [10, с. 79]. Як же регулюються ці питання в інших зарубіжних країнах? Наприклад, за дослідженням в англосаксонській системі права (США, Велика Британія) не існує кодифікованого закону-кодексу. У США кримінальне провадження вважається розпочатим 3 моменту реєстрації заяви чи повідомлення про злочин, яких щорічно реєструється від 10 до $13 \mathrm{mлн} \mathrm{[11,}$ с. 58]. У Великій Британії уповноваженими особами офріційно не оформлюється процесуальний акт про початок провадження у справі, хоча його може ініцюювати кожен із посадовців поліції, на тих же підставах, що й потерпілий, і в цій країні не відомі такі фоорми досудового розслідування, як дізнання та слідство. Країни романо-германської правової сім'ї (Німеччина, Франція) характеризуються переважно правовими нормами, що закріплені в кодифікованих нормативних актах, зокрема, що регулюють досудове і судове провадження. У Німеччині не існує стадії порушення кри- мінального провадження. Приводами для його початку $\epsilon$ службовий розсуд поліції і прокуратури, заяви приватних осіб та скарги потерпілих у справах приватного обвинувачення, представників громадської влади, судових органів. Після початку провадження прокурором, розслідування проводить поліція, (окрім складних і важливих справ), у формі "вільного доказування" [9, c. 37]. У Франції також відсутня стадія початку кримінального провадження, а існує декілька різновидів попереднього дізнання. За результатами дізнання прокурор ініціює кримінальний позов (спеціальну вимогу, кримінальну справу) про застосування покарань щодо підозрюваних або за фактом злочину, який направляється судовому слідчому для проведення досудового слідства [12, с. 168]. На основі порівняльного аналізу питання початку кримінального провадження в західноєвропейських країнах та США, незалежно від їхніх правових систем, можна зауважити таке: початок кримінального провадження не пов'язується зі складанням процесуального документа; дії повязані з його початком чітко не виокремлюються в окрему стадію кримінального судочинства. Водночас при всій позитивності зарубіжного досвіду, за визначенням О. Вакулика і Ю. Азарова, їхнє процесуальне законодавство характеризується багатьма дискусійними положеннями, наявністю певних проблем у правозастосуванні і важливо упередити це "перенесення" у національне законодавство. Наприклад, у більшості зарубіжних країн повноваженнями щодо прийняття заяв чи повідомлень про злочини наділена лише поліція, що звужує реалізацію прав і законних інтересів громадян таких країн. Водночас, згідно із ч. 4 ст. 214 КПК України такий обов'язок покладено на прокурора, слідчого, уповноважену на прийняття та реєстрацію заяв особу. Наявність такої норми дозволяє нашим громадянам й особам, що перебувають на ії території, можливість звернутись до будь-якого державного і правоохоронного органу та повідомити про вчинений злочин, а не "шукати" поліцейського [9, с. 40]. У цьому є перевага нашого національного законодавства. У зв'язку з викладеним слід навести наголошення В. Нора i Н. Бобечка, що не слід здійснювати сліпе запозичення елементів моделей кримінального процесу зарубіжних держав (особливо англо-американської) без урахування особливостей правової системи України, історичних традицій вітчизняного державотворення, рівня професіоналізму та правосвідомості правозастосувачів, менталітету населення та інших чинників. Законодавцю не варто бездумно копіювати зарубіжний досвід, а перед уведенням відповідних новел слід зрозуміти, чому у кримінально-процесуальному законодавстві інших держав діє той чи інший інститут. Лише за такого підходу, ґрунтуючись на власному досвіді, нововведення легше інтегрувати до вітчизняної моделі кримінального судочинства, узгодити їх із наявними процесуальними інститутами, обґрунтувати доцільність змін кримінального процесуального законодавства $[13$, с. $118-119]$

У наступний час в Україні слідчими реєструються усі заяви та повідомлення про злочини, без дослідчої (попередньої) перевірки за фрормальними ознаками, що перевантажує слідчі підрозділи, у яких кількість розслідуваних злочинів на одного слідчого у середньому по країні в 2017 р. складала - 260, а в Кіровоградській обл. - 431, Запорізькій - 345, Херсонській - 328, Донецькій 299, Черкаській - 264, Львіській, Одеській по - 289, та м. Київ - 369. Наприклад, усього у 2017 р. слідчими 
поліції розслідувалось 2 млн 55 тис. кримінальних проваджень, що на 10,4 \% більше ніж у 2016 р. Із цієї кількості закінчено розслідування 875 тис. (42,6\%) кримінальних проваджень проти 819 (44 \%) у 2016 р. Раніше, у 2012 р. по Україні всього обліковано - 443700 злочинів, відповідно у 2013 р. - 563 560, у 2014 р. - 529139 , у 2015 р. - 565182 , у 2016 р. - 612 310, у 2017 р. 523911 злочинів. У цьому контексті слід навести аргументацію Ю. Аленіна та О. Мілевського, які слушно зауважили, що нині основне навантаження лягає виключно на слідчого. 3 огляду на це слідчі вимушені перевіряти найабсурднішні заяви про злочини, тоді як від них вимагається розслідування тяжких і особливо тяжких злочинів [15, с. 110; 14, с. 108-114], що ми підтримуємо.

У зв'язку із цим унесено значну кількість пропозицій з метою удосконалення його положень щодо початку кримінального провадження, які можна згрупувати, зокрема, на такі: 1) запровадження положень у КПК України щодо здійснення дослідчої (попередньої) перевірки заяв і повідомлень про злочини перед реєстрацією у ЄРДР; 2) законодавче закріплення "кримінальних проступків", що регламентовано чинним КПК України; 3) удосконалення КПК України щодо встановлення приводів і підстав для початку кримінального провадження. Аналізуючи зазначені й інші пропозиції, вважаємо, що не $є$ доцільним упроваджувати в чинний КПК України дослідчу (попередню) перевірку заяв і повідомлень про злочини, оскільки в органах поліції знову буде створюватись негативна практика в ході їх перевірок. А головне, будуть складатися умови можливих зловживань. Це підтверджується у сучасних у мовах тим, що, незважаючи на виконання "Кардинальної трансформації критеріїв оцінки роботи поліцейських - із кількісних на якісні", в якій зазначено: "Національна поліція відмовляється від статичтичних методів оцінки роботи підрозділів і співробітників. Для нас важливі не кількісні, а якісні показники роботи співробітників поліції", що свідчить про намагання відмовитись від "вимагання" показників, зокрема щодо підвищення відсотка розкриття. Водночас за дослідженням встановлено, що на практиці все ж таки в регіонах продовжується тенденція про витребування таких показників від працівників поліції та слідчих. Зокрема, наприкінці звітного періоду працівників органів досудового розслідування змушують збільшувати кількість повідомлень про підозру або закривати кримінальні провадження, що складає певний відсоток від загальної кількості зареєстрованих злочинів і загалом впливає на збільшення відсотка розкриття злочинів. Крім цього, із 2018 р. введено показник кількості закінчених слідчими кримінальних проваджень. Це у сучасному стані підтвержують і В. Нор та Н. Бобечко, зокрема, про те, що діє система показників із розкриття злочинів, яка має обвинувальний ухил, порушує права, свободи й інтереси особи, засади презумпції невинуватості, а також всебічного, повного та неупередженого 3'ясування обставин кримінального провадження [13, с. 112-121]. Вирішенню питань "фрільтру" заяв і повідомлень про злочини, на нашу думку, може сприяти ухвалення законодавства щодо запровадження кримінальних проступків. Окремої уваги і підтримки заслуговує наукова позиція В. Фрича, О. Комарницької, Г. Глобенка та інших учених про те, що у положеннях гл. 41 КПК України не в повній мірі враховані особливості процесуальної діяльності окремих службових осіб на початку досудового розслідування при виявленні ознак кримінального правопорушення в разі виявлення ознак кримінального правопорушення на морському чи річковому судні, що перебуває за межами України, досудове розслідування розпочинається негайно; відомості про нього вносяться до ЄРДР при першій можливості (ч. 3 ст. 214 КПК України). Крім цього, законодавець не передбачив механізму початку досудового розслідування у разі виявлення ознак злочину на повітряному транспорті, а також на території дипломатичних представництв чи консульських установ України, що розміщуються за її межами. Керівник дипломатичного представництва чи консульської установи України також не визначений як процесуальна особа, що уповноважена розпочати досудове розслідування. Зазначена прогалина підлягає усуненню в законодавчому порядку [16, с. 111-120; 10, с. 49-51]. Наполягаючи на пропозиції щодо запровадження винесення постанови про порушення кримінальної справи при реєстрації заяви до ЄРДР, слід зауважити, що в науці були і залишаються дискусійними питання щодо визначення приводів і підстав за наявності яких посадові особи можуть вирішувати питання про винесення постанови про початок досудового розслідування. Приводом $є$ інформація про злочин з погляду ії форми, а підстава з точки зору ії̈ змісту, але на жаль, ці визначення законодавець оминув, зокрема, у ч. 1 ст. 214 чинного КПК України. Це призводить до неоднозначності при правозастосуванні та $є$ суттєвою проблемою доступу громадян до правосуддя та можливих зловживань, хоча й ч. 2 ст. 94 попереднього КПК України 1960 р. була "розмитою" і неконкретною у визначенні "достатності даних, що вказують на ознаки злочину". 3 огляду на це, як теоретично, так і практично зазначені питання можуть бути вирішені з погляду встановлення ознак складу злочину чи кримінального проступку (злочини невеликої тяжкості) щодо кожної конкретної заяви, за внутрішнім переконанням слідчого, прокурора. Але при цьому, на думку Н. Жогіна і Ф. Фаткулліна із цих питань не можна надати надійний рецепт, не скочуючись до теорії формальних доказів [18, с. 122-125]. Слід підтримати наукові позиції вчених, що підставою для винесення постанови про порушення кримінального провадження може бути наявність ознак (мінімальну вірогідність вчинення) суспільно небезпечного діяння. Приводом до цього може служити: інформація про вчинений злочин у тому обсязі, який $є$ необхідним та достатнім для орієнтовного висновку про можливість учинення зазначеного і його кримінальноправову кваліфікацію; відповідність вимозі ідентиорікувати особу негайно, або в близькому майбутньому, яка повідомляє про вчинене, при цьому повинна бути дотримана вимога, що така заява не повинна бути анонімною. Окремим винятком до останнього, на нашу думку, слід вважати прийняття анонімної заяви (і по телефону) про терористичний акт, що готується чи закладення вибухівки у громадських місцях (незалежно від мотивів), або викрадення людини, ураховуючи їхню суспільну небезпечність. Крім вищезазначених підстав, за визначенням Ю. Аленіна у ст. 214 КПК України є суттєва прогалина щодо закріплення підстави для забезпечення заходів безпеки особи заявника, або членів його сім'ї і близьких родичів, якщо шляхом погроз або інших протиправних дій щодо них здійснюються спроби вплинути на заявника, на відміну від ст. 521-532 КПК України 1960 р. [15, с. 198-203]. У разі відсутності приводів і підстав слід підтримати пропозицію науковців про законодавче закріплення відмови слідчим, прокурором у реєстрації заяви чи повідомлення до ЄРДР, без проведення дослідчої перевірки [9, с. 145]. 
Висновки. Узагальнення і порівняльний аналіз КПК України 1960 і 2012 рр. та практики їхнього застосування, дослідження і вивчення різних наукових позицій учених щодо концепції початку досудового розслідування свідчить про підвищену увагу на всіх історичних етапах до зазначеної проблеми. Незважаючи на різновекторні погляди вчених щодо визначення понятійного апарату і процесуального механізму, слід наголосити, що всі наукові позиції обґрунтовують особливе значення законодавчої регламентації початку досудового розслідування, який визначає подальший напрям розслідування для слідчого, прокурора й обов'язок щодо необхідності дотримання прав, свобод і законних інтересів усіх учасників кримінального провадження та залучених до нього осіб. 3 метою удосконалення законодавства щодо початку досудового розслідування, і враховуючи викладене, на нашу думку, було б доцільним здійснити таке: 1) 3 огляду на досвід прибалтійських країн, затвердити прийнятий у 2019 р. Верховною Радою України Закон "Про кримінальні проступки", без запровадження проведення дослідчої перевірки заяв і повідомлень про кримінальний проступок та привести у відповідність до КПК України відомчі нормативно-правові акти правоохоронних органів, що наділенні правом проведення обліку і досудового розслідування, що буде запобігати зловживанню з боку посадових осіб, які проводитимуть відповідні обліки щодо заяв і повідомлень про злочин; 2) внести доповнення до чинного КПК України, які б регламентували слідчому, прокурору поряд із внесенням відомостей про заяви та повідомлення про злочини до ЄРДР, за наявності приводів і підстав (без проведення дослідчої перевірки), виносити ще й постанову про початок проведення досудового розслідування (кримінального провадження), 3 повідомленням про це зацікавлених учасників кримінального провадження, а у разі відсутності приводів та підстав, відмовляти в реєстрації. 3 цією метою доцільно підтримати пропозицію вчених щодо доповнення КПК України новою статею. 214-1 "Відмова від внесення відомостей до Єдиного реєстру досудових розслідувань" (без проведення дослідчої перевірки). Утім, ураховуючи довготривалу дискусію, різновекторні позиції учених і практиків, в одній статті неможливо розглянути увесь спектр наявних і порушених проблемних питань, розв'язання яких має суттєве значення у науці та правозастосовній діяльності органів досудового розслідування, прокуратури, тому вони є не остаточними і потребують подальшого дослідження або наукового вивчення.

Список використаних джерел:

1. Лобойко Л.М. Реформування кримінального-процесуального законодавства в Україні (2006-2011 роки). Ч. 1: Загальні положення і досудове провадження : монограф. К.: Істина. 2012. 228 с.

2. Кузнецов Н.П. Доказывание на стадии возбуждения уголовного дела. Воронеж: Изд-во Воронежского ун-та. 1983. 117 с.

3. Балашов А.Н. Действительно ли возбуждение уголовного дела первоначальная стадия уголовного процесса. Социалистическая законность. 1989. № 8. С. 53-54

4. Уголовный кодекс Украины (с изм. и доп. по сост. на 1 февраля 1998 г.). Х.: ООО "Одиссей", 1998. 24 с.

5. Уголовный кодекс Украины : науч.-практ. комент. / отв. ред. С.С. Яценко, В.И. Шакун). К.: Правові джерела, 1998. 1088 с.

6. Ігнатов О.М. Протидія загальнокримінальній насильницькій злочинності в Україні : монограф. Х.: Диса Плюс. 2013. 650 с.

7. Погорецький М.А. Початок досудового розслідування : окремі проблемні питання. Вісник кримінального судочинства. 2015. № 1. С. 93-103.

8. Черечукіна Л.В. Точка відліку кримінального провадження за проектом КПК України (чи відповідає механізм кримінального провадження принципам публічності та змагальності?) : мат. міжнар. наукпракт. конф. "Забезпечення законності в діяльності органів досудового слідства та дізнання" (Луганськ, 26 березня 2012 р.) / редкол.: Л.В. Черечукіна, О.Г. Русанова / МВС України, Луганський держ. ун-т внутр. справ ім. Е.О. Дідоренка. Луганськ: РВВ ЛДУВС ім. Е.О. Дідоренка, 2012. С. 5-12.

9. Вакулік О.А., Ю.І. Азаров Початок досудового розслідування у кримінальному провадженні : навч. посіб. К.: "Центр учбової літератури". 2015. 184 с.

10. Глобенко Г.І. Деякі питання регламентації початку досудового розслідування у кримінальному процесі України. Вісник Харківського національного університету внутрішніх справ. 2016. № 3 (74). С. 76-84.

11. Курдова А.В. Права защитника в США при проведении полицией процессуальных действий в отношении подозреваемого, обвиняемого. Юрист. 1998. № 7. С. 58.

12. Голяк Л.В., Мацко А.С., Тюріна О.В. Порівняльне законодавство: курс лекцій. К.: МАУП, 2004. 200 с.

13. Нор В., Бобечко Н. Кримінально-процесуальне право України : надбання, загрози, очікування. Право України. 2017. № 5. С. 112-121.

14. Мілевський О.О. Початковий етап досудового розслідування злочинів, вчинюваних у зоні Чорнобильської АЕС. Міжнародний юридичний вісник: зб. наук. праць Національного ун-ту держ. податк. служби України. 2015. Вип. 1(2). С.108-114.

15. Аленін Ю.П. Початок досудового розслідування за КПК України 2012 року. Юридичний часопис Національної академії внутрішніх справ. 2012. № 1. С. 198-203.

16. Фрич В.І., Комарницька О.Б. Щодо законного затримання особи на повітряному, морському чи річковому судні, що перебуває за межами України під прапором або з розпізнавальним знаком України, якщо це судно приписано до порту, розташованого в Україні. Часопис цивільного і кримінального судочинства. 2013. № 5 (14). С. 111-120.

17. Кримінальний кодекс України (із змін. та доп. станом на 5 березня 2012 р.). Х.: Одіссей, 2012. 232 с.

18. Жогин Н.В., Фаткуллин Ф.Н. Возбуждение уголовного дела. М.: Госюриздат, 1961. 206 с

19. Кримінальний процесуальний кодекс України: станом на 1 вересня 2018 р. Х.: Право. 2018. 386 с.

Received: $05 / 04 / 2019$ 1st Revision: $17 / 05 / 2019$ Accepted: $20 / 06 / 2019$

A. Yukhno, Doktor of Sciences (Law), Professor, Head of Department Kharkiv National University of Internal Affairs, Kharkiv, Ukraine

\section{SOME PROBLEMATIC ISSUES OF LEGISLATIVE AND APPLIED IMPROVEMENT OF THE INITIAL STAGE OF PRE-TRIAL INVESTIGATION}

The author of the article conducts a comparative analysis of the previous and existing criminal procedural legislation of Ukraine regarding the procedural institution of starting criminal proceedings. Certain gaps and inconsistencies in the current criminal procedural legislation of Ukraine on these issues which cause justifiable complaints from all participants in the criminal proceedings are identified. The author analyses genesis, individual scientific points of view and the state of discussion among scientists and practitioners in this direction, as a result of which it is established that the problematic issues raised in the article are not resolved theoretically and in an applied aspect, including the previous and in the current criminal procedural legislation of Ukraine. In the context of the issue under consideration, the legislation of foreign countries is examined including post-Soviet states, Anglo-American and Roman-German legal families. As a result, many Ukrainian scientists have concluded that the foreign experience cannot be applied in national legislation without taking into account the national peculiarities of the legal system of Ukraine, the historical traditions of state construction, the level of professionalism and legal awareness of those who apply legislation, the mentality of the population and other factors. Moreover, the author pays paid attention to the study of discussion questions on the grounds and reasons for resolving the procedural problem of issuing a resolution when instituting criminal proceedings and when making statements and reports on committed criminal offenses in to the single register of pre-trial investigations, as well as refusing to register on these issues. The author makes some suggestions for improving the existing criminal procedural legislation and the regulatory framework in the context of the issues discussed.

Keywords: the beginning of the investigation, criminal proceedings, improvement, a notice, an investigator, a prosecutor, disclosure, regulation. 
References:

1. Loboiko L.M. Reformuvannia kriminalno-procesualnogo zakonodavstva Ukrainu (2006-2011 roki). Chastina 1. Zagalni pologennia i dosudove provadgennia : monograf. K.: Istina, 2012. $228 \mathrm{~s}$.

2. Kuznecov N.P. Dokazivanie na stadii vozbugdenia ugolovnogo dela. Voroneg: Izdatelstvo Voronegskogo universiteta, $1983.117 \mathrm{s.}$

3. Balashov A.N. Deistvitelno li vozbugdenie ugolovnogo dela - pervonachalnaya stadia ugolovnogo processa. Socialisticheskaya zakonnost.1989. № 8 . S. $53-54$.

4. Ugolovnii kodeks Ukrainu (s izmeneniami i dopolneniami po sosotoyaniu na 1 fevralya 1998 goda). Kharkiv: OOO Odissei, 1998.24 s.

5. Ugolovnii kodeks Ukrainu: naychno-prakticheskii komentarii (otvetstvennie redaktora Yatsenko S.S., Shakun V.I.). Kyiv: Pravovi dgerela, 1998. $1088 \mathrm{~s}$

6. Ignatov O. M. Protidia zagalnokriminalnii nasilnickii zlochinnosti v Ukraini : monograf. Kharkiv: Disa plus, $2013.650 \mathrm{~s}$.

7. Pogoreckii M.A. Pochatok dosudovogo rozsliduvwnnia: okremi problemni putaniia. Visnik kriminalnogo sudochinstva. 2015 . № 1. S. 93-103.

8. Cherechukina L.V. Tochka vidliky kriminalnogo provadgennia za proetom KPK Ukrainu (chi vidpovidae mehanizm kriminalnogo provadgennia prinzipam publichnosti ta zmagalnosti): materialu miznarod. Nayk.-praktichn. Konferencii "Zabezpechennia zakonnosti dialnosti organiv dosudovogo slidstva ta diznannia" (Lugansk, 26 bereznia 2012 roku) / redkol.: Cherechukina L.V., Rusanova O.G. / MVS Ukraini, Luganskii dergavnii universitet vnutrishnih sprav im. O.E. Didorenka. Lugansk: RVV LDUVS im. O.E. Didorenka, 2012. S. 5-12.

9. Vakulik O.A., Azarov U.I. Pochatok dosudovogo rozsliduvannia u kriminalnomy provadgenni: navch. posib. Kyiv: " Centr uchbovoi literaturi", 2015.184 s.

10. Globenko G.I. Deyaki putannia reglamentacii pochatky dosydovogo rozslidyvannia y kriminalnomy processi Ukrainu. Visnil Kharkivskogo nacionalnogo yniversitety vnytrishnih sprav. 2016. № 3 (74). S. 76-84. S. 58 .

11. Kurdova A.V. Prava zashitnika $\vee$ SHA pri provedenii policiei pricesualnih deistvii $\vee$ otnoshenii podozrevaemogo, obvinyarmogo. Urist. 1998. № 7 .

12. Golyak L.V., Macko A.S., Turina O.V. Porivnyalne zakonodavstvo: kurs lekcii. Kyiv: MAUP. 2004. $200 \mathrm{~s}$.

13. Nor V., Babchenko N. Criminalno-processualne pravo Ukrainu: nadbannya, zagrozi, ochikuvanniia. Pravo Ukrainu. 2017. № 5. S. $112-121$.

14. Milevskii O.O. Pochatkovii etap dosudovogo rozsliduvannia zlochiniv, vchinuvanuh u zoni Chornobilskoi AES. Miznarodnii uridichnii visnuk : zbirnik nuykovih praz Nacionalnogo universitety dergavnoi podatkovoi sluzbu Ukrainu. 2015. Vup. 1(2). S. 108-114.

15. Alenin U.P. Pochatok dosudovogo rozsliduvania za KPK Ukrainu 2012 roku. Uridicnii chasopis nacionalnoi akademii vnutrishih sprav. 2012. №1. S.198-203

16. Frich V.I., Kmarnicka O.B. Shodo zakonnogo zatrumannaya osobu na povitryanomy, morskomy chi richkovomy sudni, sho perebuvae za mezami Ukrainu pid praporom abo z rozpiznavalnim znakom Ukrainu. Chasopiszivilnogo i kriminalnogo sudochinstvs. 2013. № 5(14). S. 111-120.

17. Kriminalnii Kodeks Ukrainu (iz zminmu ta dopovnenniamu stanom na 5 bereznya 2012 roku). Kharkiv: Odissei, $2012.232 \mathrm{~s}$.

18. Zgogin N.V., Fatkullin F.N. Vozbuzdenie ugolovnogo dela. M.: Gosurizdat, 1961. 206 s.

19. Kriminalnii procesualnii kodeks Ukrainu : stanom na 1 veresnya 2018 roky. Kharkiv: Pravo, 2018. 386 s. 